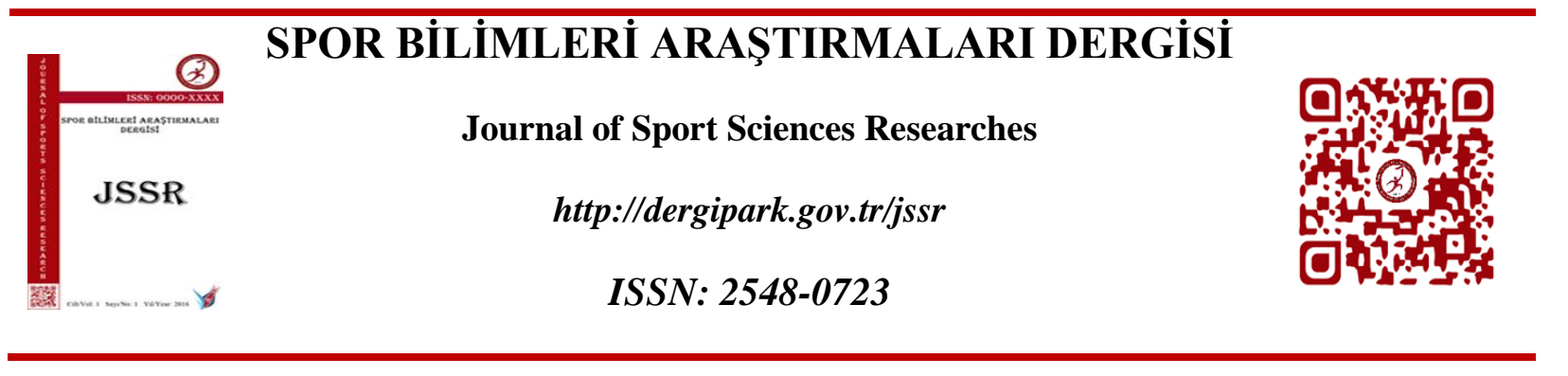

\title{
Spor Bilimleri Fakülteleri Antrenörlük Öğrencilerinin Otantik Liderliklerinin Yaşam Boyu Öğrenme Eğilimleri ve Duyarlı Sevgi Becerileri Açısından İncelenmesi
}

\section{Çiğdem ÖNER ${ }^{1}$}

$\ddot{\mathbf{O} z}$

Bu çalışmanın amacı, Spor Bilimleri Fakülteleri Antrenörlük lisans öğrencilerinin yaşam boyu öğrenme eğilimleri ile duyarlı sevgi becerilerinin otantik liderlik davranışlarını yordayıp yordamadığının incelenmesidir. İlişkisel tarama modeli ile gerçekleştirilen araştırmanın evrenini, ulaşılabilir Spor Bilimleri Fakülteleri Antrenörlük Bölümleri lisans öğrencisi 354 gönüllü katılımcı oluşturmaktadır. Araştırmanın değişkenlerinin analizinde Otantik Liderlik Ölçeği (Walumbwa ve ark., 2008), Yaşam Boyu Öğrenme Eğilimleri Ölçeği (Diker Coşkun, 2009) ve Duyarlı Sevgi Ölçeği (Sprecher ve Fehr, 2005) kullanılmıştır. İstatistiki analizler için NCSS (Number Cruncher Statistical System) 2007 (Kaysville, Utah, USA) programından yararlanılmış, veriler değerlendirilirken tanımlayıcı istatistiksel metodların (ortalama, standart sapma, en düşük-en yüksek değer, ortanca, frekans, oran) yanı sıra normal dağılım göstermeyen nicel verilerin iki grup karşılaştırılmasında Mann Whitney U testi, ölçekler arası ilişkilerin değerlendirilmesinde Spearman korelasyon analizi, çok değişkenli analizlerin değerlendirilmesinde Linear Regresyon analizi'nden yararlanılmıştır. Araştırmada anlamlılık düzeyi 0.05 ve 0.01 olarak alınmıştır. Ölçekler arası ilişkilerin "Korelasyon Analizi” ile incelenmesi sonucunda, Otantik Liderlik Ölçeği toplam puanı ile Yaşam Boyu Öğrenme Eğilimleri Ölçeği toplam puanı arasında \%25,7 düzeyinde (r:0,257; $\mathrm{p}=0,001 ; \mathrm{p}<0.01$ ), Otantik Liderlik Ölçeği toplam puanı ile Duyarlı Sevgi Ölçeği toplam puanı arasında \%28,3 düzeyinde $(\mathrm{r}: 0,283 ; \mathrm{p}=0,001 ; \mathrm{p}<0.01)$ ve Yaşam Boyu Öğrenme Eğilimleri toplam puanı ile Duyarlı Sevgi Ölçeği toplam puanı arasında $\% 29,8$ düzeyinde (r:0,298; $\mathrm{p}=0,001 ; \mathrm{p}<0.01)$ pozitif yönlü istatistiksel olarak anlamlı ilişkiler saptanmıştır. Yapılan regresyon analizlerinde, otantik liderlik düzeyi toplam puanı üzerine Yaşam Boyu Öğrenme Eğilimleri Ölçeğinin motivasyon ve öğrenmeyi düzenlemede yoksunluk alt boyut puanları ve Duyarlı Sevgi Ölçeği toplam puanının etkileri anlamlı bulunmuştur, farklı bir deyişle Yaşam Boyu Öğrenme Eğilimleri Ölçeği alt boyutları olan "motivasyon" ve "öğrenmeyi düzenlemede yoksunluk" ile duyarlı sevgi toplam puanının otantik liderlik düzeyinin yordayıcısı olduğu söylenebilir.

\author{
Orijinal Makale \\ Yayın Bilgisi \\ Gönderi Tarihi: 12.07.2017 \\ Kabul Tarihi: 16.12 .2017 \\ Online Yayın Tarihi: 29.12.2017
}

DOI: $10.25307 / j s s r .328103$

Egzersiz ve spor psikolojisi, antrenörlük, otantik liderlik, yaşam boyu ögrenme eğilimleri, duyarlı sevgi.

\footnotetext{
${ }^{1}$ Sorumlu yazar:

E-mail: esenlik@cigdemoner.com.tr, 05323540889
} 


\title{
Investigation of Authentic Leadership in Terms of Lifelong Learning Tendency and Compassionate Love Skills of Coaching Students of Faculty of Sports Sciences
}

\begin{abstract}
The purpose of this study was to investigate the prediction of the authentic leadership behaviours according to the lifelong learning tendencies and compassionate love skills of coaching students of the Faculty of Sports Sciences. The participants of the study were 354 (118 women, 236 men) volunteers in reacheable area. The research was designed according to the relational screening model. By collecting the relevant data, Authentic Leadership Questionnaire (Walumbwa et all., 2008), Lifelong Learning Tendency Scale (Diker Coşkun, 2009) and Compassionate Love Scale (Sprecher and Fehr, 2005) were used for the analysis of variables of the research. For statistical analyses NCSS (Number Cruncher Statistical System) 2007 (Kaysville, Utah, USA) was used. The findings were analyzed through descriptive statistical methods (average, standard deviation, median, frequency, percentage, minimum, maximum, ratio) and besides, Mann Whithney U was used for comparing of two groups which were non-normally distributed quantitative data and Spearman Correlation analysis was used in determining the interscale relationships. Additionally, Linear Regression analysis was used in evaluating the multivariate analysis of determining the effect of the Lifelong Learning Tendencies and Compassionate Love Levels on the Authentic Leadership Levels of the Sports Coaching Students studying in Faculty of Sport Sciences. Significance level in the study was taken as 0.05 and 0.01 . As a result of the examination of the relationship between the Authentic Leadership, Lifelong Learning Tendency and Compassionate Love Levels with Correlation analysis a meaningful relationship has been emerged between Authentic Leadership and Lifelong Learning Tendency Scores on \%25,7 (r:0,257; $\mathrm{p}=0,001 ; \mathrm{p}<0.01)$, between Authentic Leadership and Compassionate Love scores on \%28,3 (r:0,283; $\mathrm{p}=0,001 ; \mathrm{p}<0.01)$, and between Lifelong Learning Tendency and Compassionate Love Scores on \%29,8 (r:0,298; $\mathrm{p}=0,001 ; \mathrm{p}<0.01)$. Finally, in order to examine the Effects of the Lifelong Learning Tendency and Compassionate Love Levels on the Authentic Leadership Regression Analyses was performed. It was concluded that Authentic Leadership Level is affected from the subscales "motivation" and "deficiency on regulation of learning" of Lifelong Learning Tendency Scale and Compassionate Love Level, in other words the subscales "motivation" and "deficiency on regulation of learning" of Lifelong Learning Tendency Scale and Compassionate Love are the predictors of Authentic Leadership.
\end{abstract}

Keywords:

Exercise and sports psychology, sports coaching, authentic leadership, lifelong learning tendency, compassionate love.

\section{GİRIS}

Bilim ve teknolojideki gelişmelerin günlük yaşamın neredeyse her anına egemen olduğu bilgi çağının öğrenen toplumlarında, deneyimsel süreçlere eklemlenen sosyo-kültürel, sosyoekonomik ve teknoloji merkezli gelişim, değişim ve dönüşüm olguları, gereksinim duyulan yetişmiş insan profilini hızla farklılaştırmakta, pek çok sektörde olduğu gibi spor bilimleri alanında da bireysel ve toplumsal duyarlılığı yüksek, yenilikçi, öğrenmeye açık, kendini geliştiren, üst düzey niteliklere sahip özgün insan gücünü gerekli kılmaktadır.

Liderlik ve antrenörlük konu ve duruma özel yaklaşımları gerektirmekte (Konter, 1996:9), antrenörlerin tutum ve davranışları spor branşına, sporcuya, sporcunun yaş, cinsiyet ve benzer özelliklerine göre farklılık gösterebilmektedir. Doğan'a (2015:173) göre, antrenör kuramsal bilgi ve deneyimini birleştirerek sporcuyu yeteneğine uygun biçimde yönlendiren, çalıştıran, yarışmalara hazırlayan, liderlik yapan bir spor insanıdır. Donuk (2007:145) antrenörleri, hazırladıkları uzun vadeli antrenman taslaklarına canlılık kazandıran, sporcuların dayanıklılık, çeviklik ve nefes gücünü artırarak mücadele yeteneğini güçlendiren ve kişiliklerinin gelişimlerini sağlarken toplumsal yapılarının da mimarı olan eğitimciler olarak yorumlamıştır. 
Serin (2016:34), antrenörün temel çalışma alanının sporcu veya takım olduğunu bildirmiş, performans sporunun asıl hedefi olan başarıya ulaşmada sağlıklı antrenör-sporcu ilişkisinin gerekli en önemli koşul olduğunu öne sürmüştür. Araştırmacıya göre, bu ilişki genel manada bir kişi veya bir grupla ilişki olarak düşünülse de amaçları, işleyişi ve yapısının daha belirli olması nedeniyle sıradan insan ilişkisinden farklılaşmaktadır. Doğan (2004:176-177), antrenörün sporcu veya takımla ilişkisinin hedefe uygun biçimde yürütülmesinde; taraflara has niteliklerin öneminin üzerinde durmuş, söz konusu ilişkinin sağlıklı ilerleyişi ve başarıyla sonuçlandırılmasında antrenörün özellikleri ve çalışma yöntemini iki ana unsur olarak görmüştür. Antrenörün alması gerekli en önemli kararlardan birinin antrenörlük stili olduğuna işaret eden Martens (1998:11), antrenörlük stilinin; hangi beceri ve stratejilerin öğretileceği, nasıl karar alınacağı, antrenman ve yarışmaya nasıl hazırlanılacağı, oyunculara disiplin kazandırma amacıyla hangi yöntemlerin kullanılacağı ve sporculara karar alma süreçlerinde hangi rollerin verileceğinin saptanmasında etkili olduğunu ifade etmiştir.

Uygulanan her çeşit antrenmanın bir boşlukta değil, tarihsel, çevresel ve sosyo-kültürel bir ortam içerisinde meydana geldiği (Konter, 2004:16) dikkate alındığında, tüm zamanları kavrayan bir liderlik tarzı olarak otantik yaklaşımın yenilikçiliğe ve çağdaşlığa uzanan sürecin uzantısı olarak spor alanında da kullanılabileceği düşünülmektedir. Bu düşünceden yola çıkılarak yürütülen araştırmada, yapılan alanyazın taraması doğrultusunda otantik liderlik, otantik liderliği destekleyici olduğu görüşüyle yaşam boyu öğrenme ile duyarlı sevgi kavramları tanımlanmış, araştırmanın yöntemi açıklanmış, bulguların ortaya konulmasını izleyerek tartışma ve sonuçlar sunulmuştur.

\section{Otantik Liderlik}

Liderlik araştırmalarının gelişimsel süreçleri boyunca gelinen nokta incelendiğinde, Avolio ve arkadaşlarının (2009:442) özetlediği şekilde; liderlik çalışmalarının daha bütüncül bir bakış açısına doğru geçiş yaptığı, alanyazına liderliğin daha pozitif ve değer odaklı biçimlerinin aktarıldığı görülmektedir. İzleyenlerin, liderlik sisteminin daha önemli bir parçası olarak değerlendirildiği günümüzde liderlerden izleyenlere doğru tek yönlü bir etkilenmeden çok lider ve izleyenler arasında çift yönlü etkileşimden söz edilmektedir. Saylı ve Baytok'un (2014:12) liderin izleyenleri etkilediği gibi izleyenlerden de etkilenmekte olduğu yönündeki görüşü, Erçil'in (2012:87) “dünya, gittikçe daha fazla birbirinden etkilenen parçaların bütünü haline gelmektedir” yorumuyla derinlik kazanmaktadır. Bu bağlamda, yönetsel alanda 'Pozitif liderlik tarzları' olarak da düşünülebilecek etik, duygusal, dönüşümsel ve tinsel benzeri değer odaklı yaklaşımlara yoğunlaşılması kaçınılmaz olmaktadir.

1970'li yılların sonlarında kavramsallaşmaya başlayan pozitif liderlik çalışmalarının merkezi unsuru olarak değerlendirilen otantik liderlik (Clapp-Smith ve ark., 2009:229), George'un (2003:11) vurguladığ 1 gibi 'kendi olmak' şeklinde tanımlanabilir. Bu kısa ve net vurgunun dayanağının, Avolio ve Gardner'ın (2005:320) otantikliğe ilişkin kavramsal açıklamalarında anlamını bulduğu düşünülmektedir. Kuramcılara göre, otantiklik Harter'ın (2002:382) da açıkladığı gibi kişinin kendi deneyimlerine bağlı olarak duygu, düşünce, gereksinim, istek, öncelik ya da inançlarını kabullenmesine farklı deyişle 'kendini bilmesine' dayalı bir süreçtir. 
$\mathrm{Bu}$ süreç, bireyin kendi iç yapısına uyum göstererek, var olan duygularını yok saymaksızın düşünmesi ve davranmasını gerektirir. Öte yandan, Kernis'in (2003:13) işaret ettiği üzere gerçek otantik yapı kendini eylemlerin seçimlerinde ortaya koyar ve kişiler arası ilişkilerde kendini gösterir; bunu yaparken olumsuzlukları ulu orta söyleme, başkaları tarafından aşırı beğenilme arzusu ve aşırı savunmacı yaklaşım gibi duyguları yadsır. Yine George'a (2003:12) göre, kişisel gelişimin yaşam boyu sürmesi gerektiğinin farkında olan otantik liderler, amaç, anlam ve değerlere öncülük ederken, saygınlık kazanmaktan çok insanları güçlendirmeyi önemsemekte, Shamir ve Eliam'ın (2005:396-397) ifadeleriyle; sözleri inançlarıyla, inançları davranışlarıyla tutarlılık sergilerken, Toor ve Ofori'nin (2008:624) saptamalarına göre yüksek bütünlük duygusu, ahlaki karakter, öz disiplin, diğer insana ilgi gösterme, güven, iyimserlik, umutlu oluş ve esneklik niteliklerini de taşımaktadırlar.

Ilies, Morgeson ve Nahrgang (2005:376) otantikliği geniş bir psikolojik yapı içinde ele alarak bu yapıyı; bireyin bulunduğu sosyal çevre içinde kendini nasıl gördüğünü ortaya koyduğu ve yaşamını öz değerlerine göre nasıl kurduğunu içine alan genel eğilimleri olarak tanımlarlar. Gardner ve arkadaşlarına (2005:345-346) göre, otantik liderler öncelikle öz farkındalık, kendini kabul, otantik eylem ve otantik ilişkiyle ulaşılabilecek otantik sürecin parçası olmayı başarmak zorundadırlar. Bu ilişkisel süreç, şeffaflık, açıklık, güven esasında şekillenmeli, anlamlı hedeflere ulaşmaya rehberlik etmeli ve izleyenlerin gelişimine odaklı olmalıdır.

Walumbwa ve arkadaşları (2008:97), önce otantiklik (Kernis, 2003), sonrasında ise otantik liderlik boyutlarının (Gardner ve ark., 2005; Illies ve ark., 2005) belirlendiği çalışmaları esas almış, Otantik Liderlik Modeli ile Otantik Liderlik Ölçeğini (ALQ) geliştirerek test etmişlerdir (akt. Topaloğlu ve Süral Özer, 2014:160). Buna göre, otantik liderliğin temelinde dört bileşen yer almaktadır: İlişkilerde şeffaflık, içselleştirilmiş ahlak anlayışı, bilgiyi dengeli değerlendirme ve öz farkındalık (Walumbwa ve ark., 2008:94).

İlişkilerde şeffaflık; kişinin durumlar için uygun olan duygu ve bilgileri açıklıkla paylaşımını içermektedir. Wong ve Cummings (2009:7) için şeffaf olabilmek, değerlerin, duyguların ve amaçların doğru bir şekilde açığa vurulması ile birlikte gerçek özün sunumunu gerektirir. Bilginin şeffaf paylaşımı, izleyenlerin lidere güven ve bağlılıklarını artırır. Otantik liderler, geri bildirim isteyerek, dinleyerek ve diğer bakış açılarını kabul ederek, önerilere göre hareket ederler ve böylelikle ilişkilerinde şeffaflık ve doğruluğu korumaya çalışırlar.

İçselleştirilmiş ahlaki bakış açısı, öz denetimin bir şeklidir. Bu bakış, kişinin içinde yer alan içsel ahlaki standartlar tarafından oluşturulan bir rehberliği ifade eder. Liderin otantik olarak görülmesinin nedeni, eylemlerinin, ifade edilen değer ve etik standartlarıyla uyumlu oluşudur.

Bilgiyi dengeli değerlendirme, Wong ve Cummings'e (2009:8) göre, değer, inanç, niyet ve davranışlar ile ilgili iç standartları düzenleme, bu standartlar ile sonuçlar arası uyuşmazlıkları çözmeyi içeren süreçtir. Kernis (2003:14), bu aşamada otantik liderlerin bilgi veya tecrübeyi abartmadan, çarpıtmadan, reddetmeden ve görmezden gelmeden tarafsızca kullandıklarını belirtmektedir. Sparrowe’a (2005:433) göre, bu kavram, öz düzenleme ve öz farkındalığın bir sonucu olarak ortaya çıkan dengeli davranışların sürekliliğini de açıklar. 
Öz farkındalık; bireyin kendi içsel çelişkili yönleri ile bu çelişkilerin duygu, düşünce, eylem ve davranışlarını etkilemesindeki rolü bilmesini, güçlü yanları ile zayıflıklarına içsel bir bakış geliştirme süreci ile dünyayı anlamlandırma biçimini kavrayışını izah etmektedir (Kernis, 2003:13; Ilies ve ark., 2005:377).

\section{Duyarlı Sevgi}

Sorokin (2005:229) sevgiyi nitelik ve nicelik bakımından sonsuz bir evrene benzetmektedir. Öyle ki sevginin dinsel, ahlaksal, varlıkbilimsel, fiziksel, biyolojik, psikolojik ve toplumsal biçimlerinden söz edilebilir. Peck (2009:81) sevginin çok geniş kapsamlı olmasından ötürü tanımlanma güçlüğüne vurgu yapmış, aşk, dostluk, yakınlık, kusursuz sevgi gibi kavramları sevginin geniş bir anlam yelpazesine sahip oluşunun göstergesi olarak değerlendirmiştir. Peck (2009:81) için sevgi, bireysel manadan taşıp başka insanlara ulaşması gereken bir unsur olduğu gibi kişinin kendisi ve bir diğerininin ruhsal gelişimini desteklemek amaciyla benliğini genişletme arzusu olarak da tanımlanabilir.

Son yıllarda doğu psikolojisindeki kavramların psikoloji dünyasında yer edinmesi merhamet, öz anlayış, affedicilik, tevazu gibi konularda bilimsel araştırmaların artmasını sağlamıştır. Bu bağlamda, olumlu kişilik özelliklerinin ölçülmesine artan ilgi, merhametin ölçülmesi ve diğer kavramlarla ilişkisinin araştırılması yolunu açmış, böylelikle farklı psikolojik ölçme araçları geliştirilmiştir. Bu amaçla geliştirilen ilk ölçeklerden biri Sprecher ve Fehr'in (2005) Duyarlı Sevgi Ölçeği'dir (Akdeniz ve Deniz, 2016:52,57). İnsanların iyi olmasına yoğunlaşan bir sevgi türü olarak duyarlı sevgi (Underwood, 2009:3) yakınlara, yabancılara, tüm insanlığa duyulan ilgi, duyarlılık, önemseme, destekleme, yardım etme ve insanı anlama üzerine yoğunluk kazanan duygu, düşünce ve davranışları (Eker, 2011:41), diğerlerinin sıkıntı ve acılarına açık olma (Lazarus, 1991:289) halinin yanı sıra fedakarlık, empati ve sempatiyi (Fehr, Sprecher ve Underwood, 2009:4) de içeren özellikleri barındırır. Saroglou (2015:116), duyarlı sevginin başkası odaklı his, inanç ve davranışlara atıfta bulunduğunu, dolayısıyla da acı çekenlere merhamet ve diğerlerinin hatta tüm insanların ilerleyişine tutkuyla bağlanmayı kapsadığını bildirmiştir.

Batson ve Oleson'a (1991; akt. Eker, 2011:41) göre, tüm toplumu kucaklayan ve süreklilik gösteren duyarlı sevgi, Underwood'un (2009:7-8,14-15) dikkat çektiği üzere iki tanımlayıc1 özellik barındırmaktadır: başkalarının iyi olma halini merkeze alan uygun güdülenme ve diğer insanların iyi oluşunu artıracak şeylerin ne olduğunu kavramayı içeren ayırt etme yetisi. Duyarlı sevginin, sözü edilen motivasyonel ve sezgisel gereksinimler dolayısıyla, sevgiyi alan bireyler üzerinde pek çok durumda olumlu sonuçlar yaratmasının beklenmekte olduğunu bildiren Fehr, Sprecher ve Underwood (2009; akt. Eker, 2011:41), yapılan bazı araştırmalarda sevgiyi veren kişide de artan özsaygı, olumlu ruh hali, daha iyi ilişkiler, düzelen sağlık, zenginleşmiş maneviyat benzeri göstergelere rastlandığını ayrıca vurgulamışlardır.

\section{Yaşam Boyu Öğrenme}

Bilginin devamlı yenilendiği, durağanlığın olanaksız hal aldığı, değişimin anahtar kelime olduğu, sosyo-ekonomik ve kültürel ölçekte önemli dönüşümlerin deneyimlendiği günümüz koşullarında; değişimin sürekliliği ve hızı, küreselleşme, ulusal ekonomiler arası rekabet, istihdam, iletişim ve teknolojiye dayalı olanakların gelişmesiyle üretilen bilgi miktarı da 
artmıştır. Ne var ki, üretilen bilginin aynı hızla güncelliğini yitirmesi, bireylerin kişisel, sosyal ve mesleki bağlamda gelişip ilerleyebilmeleri, yer aldıkları ortamlara uyum sağlayabilmeleri gibi temel gerekçeler eğitimin yaşam boyu süreçlere aktarılmasını zorunlu kılmıştır. Değişimi teşvik edici tüm bu yaşantılar; her bireyin yalnızca bilinenler konusunda değil, aynı zamanda gelecekte ortaya çıkma olasılığı bulunan öngörülemeyen durumları gözetmelerini, bu doğrultuda öğrenmelerini düzenleyici yeni eğitim hedef ve stratejilerini değerlendirmeleri gereğini doğurmuştur (Şenyuva, 2013:70; Korkut ve Akkoyunlu, 2008:179; Kaçmazoğlu, 2002:49; Akkuş, 2008:12; Güleç, Çelik ve Demirhan, 2012:34).

Turan (2005:87) yaşam boyu öğrenmeyi, bireylerin yaşam sürelerince içinde bulunacakları her tür ortam ve çevrede gereksinim duyacakları bilgi, beceri ve yeterliliklerin geliştirilmesine olanak tanıyan ve her türlü öğrenme eylemini kapsayan bir süreç olarak değerlendirmiştir. Sönmez (2014:34-38), bireyin gelişim ve değişimlere uyumunu amaçlayan bilişsel, duyuşsal ve davranışsal biçimlerdeki öğrenmesi olarak tanımladığı yaşam boyu öğrenmeyi, istendik davranışlar kazanma süreci şeklinde düşünmüş, hayatın, beceri ve duyguların sürekli değişir doğası dolayısıyla öğrenmenin her ortamda gerçekleşebileceğini öne sürmüştür. Antikainen (2001:179) yaşam boyu öğrenmenin salt hayat boyu süren değil, aynı zamanda yaşamın her alanına yayılan bir öğrenme olduğunu savunmakta, Preece (2006:308) bu olguyu "değişimler tarafindan yönetilmek yerine, değişimleri yönetmeyi sağlayacak” araç olarak önermektedir.

Alanyazında yaşam boyu öğrenme özelliklerinin bütünsellik, entegrasyon, esneklik, demokratikleştirme ve kendini gerçekleştirme şeklinde özetlendiğini öne süren Cropley ve Dave'in (1978, akt. Günüç, Odabaşı ve Kuzu, 2012:311) ardından yaşam boyu öğrenme kavramının en belirgin özelliğinin öğrenmeyi öğrenme becerisi ve sürekliliği olduğuna işaret eden Diker Coşkun (2009:52), son yıllarda çok sayıda araştırmacının, yaşam boyu öğrenme kavramını üstünlükleri, sınırlılıkları, gelişime açık yönleri, psikolojik, pedagojik, ekonomik ve sosyal boyutları açısından incelediğine vurgu yaparak ortaya konan tüm bu araştırmalarda yer bulan anahtar kavramın "öğrenmeyi öğrenme” olduğunun altını çizmiştir.

Kılıç’a (2015) göre, yaşam boyu öğrenme yaklaşımıyla eğitimde üç ana yap1 öne çıkmaktadır; öğrenmede süreklilik, yaratıcılık, kendi kendine öğrenme becerisi. Kendi kendine öğrenen birey içsel kontrol süreçlerini etkin şekilde kullanmak suretiyle bağımsız düşünme ve karar verme yetisi kazanmakta, bu ise bireyin kendini tanıması, yeterliklerinin farkına varması ve yaşamdaki yerini görebilmesi açısından önem taşımaktadır (akt. Ilıman, 2017:30). Knapper ve Cropley (2000) yaşam boyu öğrenen bireyi kendi öğrenmesini planlayan ve ölçen, öğrenmede etkin olan, gerektiğinde farklı disiplinlerden bilgileri birleştirebilen, farklı durumlarda farklı öğrenme stratejilerini uygulayabilen kişi olarak düşünmüştür (akt., Diker Coşkun, 2009:41).

\section{Araştırmanın Amacı}

$\mathrm{Bu}$ çalışmanın amacı, spor bilimleri alanında yapılan liderlik çalışmalarına yeni bir bakış kazandırmada katkı yaratacağı düşünülen otantik liderlik konusunu Spor Bilimleri Fakülteleri Antrenörlük lisans öğrencileri ölçeğinde incelemek, bu bağlamda otantik liderliğin alt boyutları olan ilişkilerde şeffaflık, içselleştirilmiş ahlak anlayışı, bilginin dengeli ve tarafsız 
değerlendirilmesi ve öz farkındalık ile motivasyon, sebat, öğrenmeyi düzenlemede yoksunluk ve merak yoksunluğu alt bileşenlerini içeren yaşam boyu öğrenme eğilimleri ve duyarlı sevgi becerileri arasındaki ilişkileri belirlemektir.

Çalışma boyunca, antrenörlük öğrencilerinin;

- otantik liderlik, yaşam boyu öğrenme eğilimleri ve duyarlı sevgi düzeyleri nasıl dağılım göstermektedir?

- otantik liderlikleri, yaşam boyu öğrenme eğilimleri ve duyarlı sevgileri arasında anlamlı bir ilişki var mıdır?

- yaşam boyu öğrenme eğilimleri ve duyarlı sevgi düzeyleri otantik liderlik özelliklerinin yordayıcisı midir?

sorularına yanıt aranmıştır.

\section{YÖNTEM}

\section{Araştırma Modeli}

$\mathrm{Bu}$ araştırma, tarama modeli olarak tasarlanmış, ilişkisel bir araştırmadır. Büyüköztürk ve arkadaşları (2015:23), ilişkileri ve bağlantıları inceleyen araştırmaları "ilişkisel araştırmalar" olarak tanımlamakta, ilişkisel araştırmanın başlıca örnekleri olarak korelasyonel ve nedensel karşılaştırma yöntemlerini göstermektedirler.

\section{Çalışma Grubu}

Araştırmanın çalışma grubunu, ulaşılabilir beş farklı Spor Bilimleri Fakültesi'nin (4 devlet, 1 vakıf üniversitesi) Antrenörlük Bölümlerinde lisans düzeyinde eğitim alan öğrenciler oluşturmaktadır. Çalışma, basit seçkisiz örnekleme yöntemi esas alınarak gerçekleştirilmiş, katılımcılar gönüllülük ilkesi gözetilerek çalışma kapsamına alınmıştır. Çalışma grubu, 118'i kadın (\%33,3), 236'sı erkek (\%66,7) olmak üzere toplam 354 gönüllüden oluşmaktadır.

\section{Veri Toplama Aracı}

Araştırmada, Tabak, Sığrı, Arlı ve Coşar'ın (2010) geçerlik ve güvenirliklerini yaparak Türkçe'ye uyarladıkları Walumbwa ve arkadaşları (2008) tarafından geliştirilmiş Otantik Liderlik Ölçeği 'OLÖ' (Authentic Leadership Questionnaire 'ALQ'), Diker Coşkun (2009) tarafından geliştirilen Yaşam Boyu Öğrenme Eğilimleri Ölçeği 'YÖEÖ' (Lifelong Learning Tendency Scale 'LLTS') ile Sprecher ve Fehr'in (2005) geliştirdikleri Türkçe uyarlamasını Akın ve Eker'in (2012) yaptığı Duyarlı Sevgi Ölçeği 'DSÖ' (Compassionate Love Scale 'CLS') kullanılmıştır. Ayrıca, veri toplama aracı olarak katılımcıların demografik bilgilerini içeren Kişisel Bilgi Formu'ndan yararlanılmıştır.

Walumbwa, Avolio, Gardner, Wensing ve Peterson (2008) tarafından geliştirilen OLÖ, özfarkındalık (4 madde), içselleştirilmiş ahlak anlayışı (4 madde), ilişkilerde şeffaflık (5 madde) ve bilgiyi dengeli değerlendirme ( 3 madde) olmak üzere dört alt boyut ve toplam 16 maddeden oluşmuştur. 5'li likert tarzında yapılandırılmış ölçekte ters kodlanmış maddelerin bulunmadığı görülmektedir. 
Diker'in geliştirdiği YÖEÖ, motivasyon (6 madde), sebat (6 madde), öğrenmeyi düzenlemede yoksunluk ( 6 madde) ve merak yoksunluğu ( 9 madde) olmak üzere 4 alt boyut ve toplam 27 madde içermektedir. Motivasyon ve sebat alt boyutlarında yer alan tüm maddeler olumlu olarak değerlendirilmekte, öğrenmeyi düzenlemede yoksunluk ile merak yoksunluğu alt boyutları olumsuz içerik taşımaktadır. 6'lı Likert tipinde düzenlenmiş ölçekte toplam puanın hesaplanmasında öğrenmeyi düzenlemede yoksunluk ile merak yoksunluğu maddeleri ters kodlanmaktadır. Ölçekten alınabilecek en düşük puan 27, en yüksek 162 olarak belirlenmiştir.

Sprecher ve Fehr'in (2005) geliştirdikleri 7'li Likert türü bir ölçme aracı olan Duyarlı Sevgi Ölçeği, 21 maddeden oluşmakta, tüm madde puanlarının toplanması ile duyarlı sevgi puanı elde edilmektedir. Ölçeğin olası puan aralığı 21 ile 147 arasında değişmektedir.

\section{Verilerin Analizi}

Araştırmadan elde edilen veriler NCSS (Number Cruncher Statistical System) 2007 (Kaysville, Utah, USA) programına aktarılmış, tüm istatistiki işlemlerdeki analizler aynı program üzerinde gerçekleştirilmiştir. Çalışma verileri değerlendirilirken tanımlayıcı istatistiksel metodların (ortalama, standart sapma, ortanca, frekans, oran, en düşük değer, en yüksek değer) yanı sıra normal dağılım göstermeyen nicel verilerin iki grup karşılaştırılmasında Mann Whitney U testi, ölçekler arası ilişkilerin değerlendirilmesinde Spearman Korelasyon Analizi kullanılmıştır. Çok değişkenli analizlerin değerlendirilmesinde ise Lineer Regresyon Analizi'nden yararlanılmıştır. Elde edilen bulguların istatistiksel analizleri anlamlılık düzeyleri $\mathrm{p}<.05$ ve $\mathrm{p}<.01$ için sınanmıştır.

\section{BULGULAR}

$\mathrm{Bu}$ bölümde, ölçme araçlarından sağlanan veriler doğrultusunda gerçekleştirilen istatistiki analizlere ilişkin bulgular, bulgulara dönük açıklamalar ve yorumlar sunulmuştur.

Kişisel Bilgi Formu'ndan elde edilen verilere göre katılımcıların; yaşları 17 ile 40 $(21,33 \pm 2,80)$ arasında değişmekte, spor geçmişleri ise 2 ila 20 yıl $(8,69 \pm 3,79)$ aralığında seyretmektedir. Katılımcıların uyguladıkları spor branşları ve haftalık antrenman sıklıklarına ilişkin veriler sırasıyla Tablo 1 ve Tablo 2'de ayrıca sunulmuştur.

Tablo 1: Spor branşına ilişkin istatistiki veriler

\begin{tabular}{|c|c|c|c|c|c|c|c|c|c|c|}
\hline & \multicolumn{10}{|c|}{ Spor Branşı } \\
\hline & Futbol & $\begin{array}{l}\text { Uzak Doğu } \\
\text { Sporları }\end{array}$ & Basketbol & Voleybol & Atletizm & $\begin{array}{l}\text { Su } \\
\text { Sporları }\end{array}$ & Boks & Hentbol & Güreş & Diğer \\
\hline $\mathbf{n}$ & 127 & 46 & 34 & 31 & 28 & 17 & 16 & 12 & 12 & 31 \\
\hline$\%$ & $\% 35.88$ & $\% 12.99$ & $\% 9.60$ & $\% 8.76$ & $\% 7.91$ & $\% 4.80$ & $\% 4.52$ & $\% 3.39$ & $\% 3.39$ & $\% 8.76$ \\
\hline
\end{tabular}

Tablo 1'e göre, çalışma grubunda en fazla üyesi bulunan spor branşı 127 kişi ile futboldur. Uzak doğu sporları 46 kişi ile ikinci, basketbol 34 kişi ile üçüncü sırada yer almaktadır. 
Katılımcıların haftalık antrenman sıklıklarına bakıldığında 102 kişinin haftada 3, 81 kişinin haftada 2, sadece 10 kişinin ise 7 ve üzerinde sıklıkta antrenman yaptığı görülmektedir (Tablo 2).

Tablo 2: Haftalık antrenman sıklıklarına ilişkin istatistiki veriler

\begin{tabular}{|c|c|c|c|c|c|c|}
\hline & \multicolumn{6}{|c|}{ Haftalık Antrenman Sıklı̆̆ı } \\
\hline & 2 & 3 & 4 & 5 & 6 & 7 ve üzeri \\
\hline $\mathbf{n}$ & 81 & 102 & 68 & 54 & 39 & 10 \\
\hline$\%$ & $\% 22.90$ & $\% 28.80$ & $\% 19.20$ & $\% 15.30$ & $\% 11.00$ & $\% 2.80$ \\
\hline
\end{tabular}

Araştırmanın katılımcısı olan antrenörlük lisans öğrencilerinin otantik liderlik, yaşam boyu öğrenme eğilimleri ve duyarlı sevgi özelliklerinin nasıl dağıldığını belirlemek üzere yapılan betimsel istatistik analiz sonuçlarına Tablo 3 'de yer verilmiştir.

Tablo 3: Otantik liderlik, yaşam boyu öğrenme eğilimleri ve duyarlı sevgi puanlarına ilişkin dağglımlar

\begin{tabular}{|c|c|c|c|c|}
\hline & $\begin{array}{l}\text { Soru } \\
\text { sayısı }\end{array}$ & $\begin{array}{l}\text { En düşük-En yüksek } \\
\text { değer (Ortanca) }\end{array}$ & Ort \pm SD & $\begin{array}{l}\text { Cronbach's } \\
\text { Alpha }\end{array}$ \\
\hline \multicolumn{5}{|l|}{ Otantik Liderlik Ölçeği } \\
\hline İlişkilerde şeffaflık & 5 & $7-25(21)$ & $20.45 \pm 3.25$ & 0.74 \\
\hline İçselleştirilmiş ahlak anlayışı & 4 & $7-20(17)$ & $16.32 \pm 2.56$ & 0.70 \\
\hline Bilgiyi dengeli değerlendirme & 3 & $3-15(13)$ & $12.16 \pm 2.31$ & 0.72 \\
\hline Öz farkındalık & 4 & $5-20(17)$ & $16.32 \pm 2.87$ & 0.77 \\
\hline Toplam & 16 & $24-80(67)$ & $65.26 \pm 9.46$ & 0.90 \\
\hline \multicolumn{5}{|c|}{ Yaşam Вoyu Öğrenme Ĕ̆glimleri Ölçĕ̆i } \\
\hline Motivasyon & 6 & $9-36(32)$ & $30.99 \pm 5.02$ & 0.88 \\
\hline Sebat & 6 & $7-36(29)$ & $27.23 \pm 5.65$ & 0.85 \\
\hline Öğrenmeyi düzenlemede yoksunluk & 6 & $7-36(31)$ & $28.88 \pm 7.17$ & 0.88 \\
\hline Merak yoksunluğu & 9 & $10-54(44)$ & $40.56 \pm 10.72$ & 0.92 \\
\hline Toplam & 27 & $63-161(134)$ & $127.66 \pm 22.04$ & 0.93 \\
\hline Duyarlı Sevgi Ölçeği & 21 & $37-147(116)$ & $113.46 \pm 20.67$ & 0.94 \\
\hline
\end{tabular}

\section{Otantik Liderlik Ölçeği (OLÖ) Puanlarının Dağılımı}

Otantik Liderlik Ölçeği'nin Cronbach Alfa iç tutarlılık değerleri incelendiğinde; ölçek toplam puanı için bu değerin 0,90 olarak saptanmış olduğu, alt boyut puanlarının ise 0,70 ile 0,77 arasında değiştiği görülmektedir (Tablo 3). Buna göre ölçeğin yüksek derecede güvenilir olduğu söylenebilir.

Ölçeğe ilişkin alt boyut puanlarının değerlendirilmesinde; ortalama ve standart sapmalarının; ilişkilerde şeffaflık için 20,45 $\pm 3,25$; içselleştirilmiş ahlak anlayışı için 16,32 2 2,56; bilgiyi dengeli değerlendirme için 12,16 $\pm 2,31$ ve öz farkındalık için 16,32 $\pm 2,87$ olarak gerçekleştiği izlenmektedir. Yapılan ölçümlerde Otantik Liderlik Ölçeği toplam puanının en düşük ve en yüksek değerlerinin 24 ile 80 arasında değişmekte olduğu bulunmuş, ortalama ve standart sapma ise 65,26 $\pm 9,46$ olarak hesaplanmıştır. Tüm boyutlar bazında, ortalama ve standart sapmalar Şekil 1'de ayrıca gösterilmiştir. 


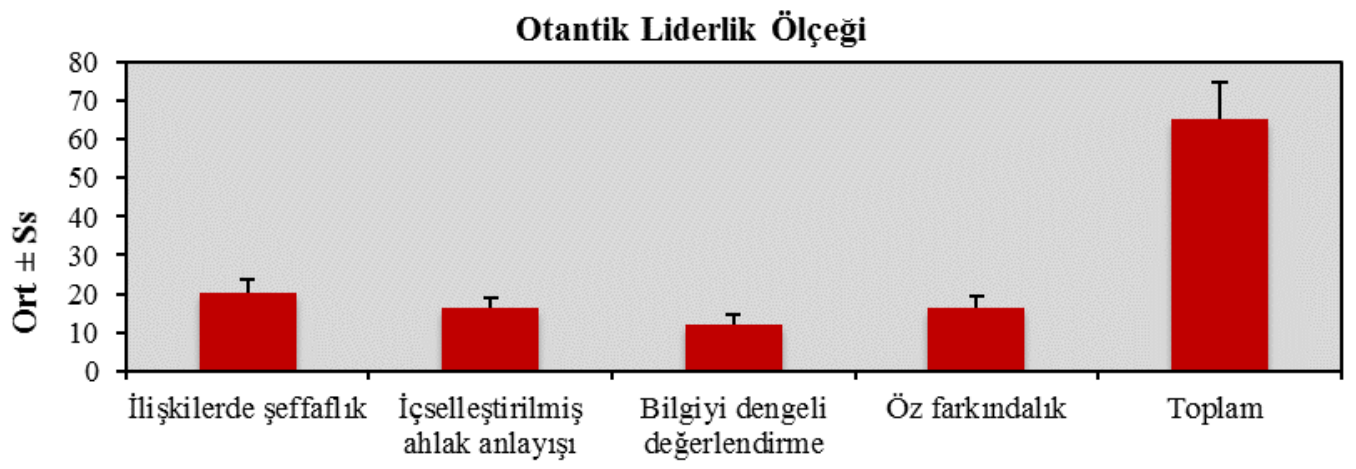

Şekil 1: Otantik Liderlik Ölçeği puanlarının dăğllımı

\section{Yaşam Boyu Öğrenme Eğilimleri Ölçeği (YÖEÖ) Puanlarının Dağılımı}

Yapılan analizler sonucunda, Yaşam Boyu Öğrenme Eğilimleri Ölçeği'nin Cronbach Alfa iç tutarlılık değerlerine bakıldığında, toplam ölçek için bu değerin 0,93 olarak hesaplandığı, alt boyut puanlarının ise 0,85 ile 0,92 arasında değiştiği izlenmektedir (Tablo 3). Buna göre ölçek yüksek derecede güvenilir bulunmuştur. Ölçeğe ilişkin alt boyutların değerlendirilmesinde; ortalama ve standart sapmalarının motivasyon için 30,99 $\pm 5,02$; sebat için 27,23 $\pm 5,65$; öğrenmeyi düzenlemede yoksunluk için $28,88 \pm 7,17$ ve merak yoksunluğu için 40,56 $\pm 10,72$ olarak gerçekleştiği görülmektedir. Yapılan ölçümlerde Yaşam Boyu Öğrenme Eğilimleri Ölçeği toplam puanının en düşük ve en yüksek değerlerinin 63 ile 161 arasında değişmekte olduğu bulunmuş, ortalama ve standart sapma 127,66 $\pm 22,04$ olarak hesaplanmıştır. Tüm boyutlar bazında, ortalama ve standart sapmalar Şekil 2'de ayrıca gösterilmiştir.



Şekil 2: Yaşam Boyu Öğrenme Ĕ̆ilimleri Ölçeği puanlarının dağılımı

\section{Duyarlı Sevgi Ölçeği (DSÖ) Puanlarının Dağılımı}

Araştırmaya katılan antrenörlük lisans öğrencilerinin duyarlı sevgi becerilerinin Cronbach Alfa değerinin 0,94 olarak saptandığı ve ölçeğin yüksek derecede güvenilir olduğu görülmektedir (Tablo 3). Duyarlı Sevgi Ölçeği toplam puanı değerleri en düşük 37, en yüksek 147 , ortalama ve standart sapma ise $113,46 \pm 20,67$ olarak hesaplanmıştır. 


\section{Ölçek Puanlarının Cinsiyetlere Göre Dağılımı}

Ölçek puanlarının değerlendirilmesi aşamasında, demografik bilgilerden cinsiyet faktörü ile bazı değişkenler arasında anlamlı farklılıklar olduğu saptanmış, tüm ölçek puanlarının cinsiyete göre dağılımlarını yansıtan bulgular Tablo 4'de sunulmuştur.

Tablo 4: Cinsiyetlere göre ölçek puanlarının değerlendirilmesi

\begin{tabular}{|c|c|c|c|}
\hline & \multicolumn{2}{|c|}{ Ort \pm SD (Ortanca) } & \multirow[t]{2}{*}{$p$} \\
\hline & Kadın & Erkek & \\
\hline \multicolumn{4}{|l|}{ Otantik Liderlik Ölçeği } \\
\hline İlişkilerde şeffaflık & $20.92 \pm 3.19(21)$ & $20.22 \pm 3.27(21)$ & 0.072 \\
\hline İçselleştirilmiş ahlak anlayışı & $16.40 \pm 2.78(17)$ & $16.28 \pm 2.45(16)$ & 0.438 \\
\hline Bilgiyi dengeli değerlendirme & $12.44 \pm 2.37(13)$ & $12.02 \pm 2.27(12)$ & $0.047 *$ \\
\hline Öz farkındalık & $16.81 \pm 2.85(17)$ & $16.08 \pm 2.86(16.5)$ & $0.010^{*}$ \\
\hline Toplam & $66.56 \pm 9.73(68.5)$ & $64.61 \pm 9.28(66.5)$ & $0.013 *$ \\
\hline \multicolumn{4}{|c|}{ Yaşam Вoyu Öğrenme Ĕ̆gilimleri Ölçeği } \\
\hline Motivasyon & $31.65 \pm 4.65(33)$ & $30.66 \pm 5.17(32)$ & 0.056 \\
\hline Sebat & $27.92 \pm 5.18(29)$ & $26.88 \pm 5.86(29)$ & 0.234 \\
\hline Öğrenmeyi düzenlemede yoksunluk & $29.42 \pm 6.41(31)$ & $28.62 \pm 7.52(31.5)$ & 0.820 \\
\hline Merak yoksunluğu & $42.19 \pm 9.93(44.5)$ & $39.75 \pm 11.03(43)$ & $0.043 *$ \\
\hline Toplam & $131.17 \pm 20.36(137.5)$ & $125.9 \pm 22.67(133)$ & $0.038^{*}$ \\
\hline Duyarlı Sevgi Ölçeği & $118.58 \pm 17.42(119)$ & $110.9 \pm 21.71(114)$ & $0.003 * *$ \\
\hline
\end{tabular}

Bulgulara göre, Otantik Liderlik Ölçeği “İlişkilerde şeffaflık” ve “İçselleştirilmiş ahlak anlayışı" alt boyutu puanları olguların cinsiyetlerine göre anlamlı farklılık göstermemektedir ( $p>0.05)$. Kadınların bilgiyi dengeli değerlendirme $(p=0,047)$ ile öz farkındalık $(p=0,010)$ puanları ve ayrıca Otantik Liderlik Ölçeği toplam puanlarının $(p=0,013)$ erkeklerden yüksek olması istatistiksel olarak anlamlı bulunmuştur $(\mathrm{p}<0.05)$.

Yaşam Boyu Öğrenme Eğilimleri Ölçeği "Motivasyon”, "Sebat” ve “Öğrenmeyi düzenlemede yoksunluk" alt boyutu puanları olguların cinsiyetlerine göre anlamlı farklılık göstermemektedir ( $p>0.05)$. Kadınların merak yoksunluğu puanlarının $(p=0,043)$ ve Yaşam Boyu Öğrenme Eğilimleri Ölçeği toplam puanının $(p=0,038)$ erkeklerden yüksek olması istatistiksel olarak anlamlı bulunmuştur $(\mathrm{p}<0.05)$.

Duyarlı Sevgi Ölçeği toplam puanı olguların cinsiyetlerine göre istatistiksel olarak anlamlı farklılık göstermektedir $(\mathrm{p}=0,003 ; \mathrm{p}<0.01)$; kadınların duyarlı sevgi puanı erkeklerden daha yüksektir.

\section{Yaşam Boyu Öğrenme Eğilimleri, Duyarlı Sevgi ve Otantik Liderlik Arasındaki İlişkinin Korelasyon Analizi ile İncelenmesi}

$\mathrm{Bu}$ araştırmada, değişkenler arasındaki ilişkinin analizi için tüm ölçekler, toplam puanları dikkate alınarak analiz edilmiş, analiz sonuçları Tablo 5 'te verilmiştir. 
Tablo 5: Ölçekler arası ilişkilerin değerlendirilmesi için yapılan Spearman korelasyon analizi

\begin{tabular}{lll}
\hline & $\mathbf{r}$ & $\boldsymbol{p}$ \\
\hline Otantik Liderlik ve Yaşam Boyu Öğrenme & 0.257 & $\mathbf{0 . 0 0 1 * *}$ \\
Otantik Liderlik ve Duyarlı Sevgi & 0.283 & $\mathbf{0 . 0 0 1}^{* *}$ \\
Yaşam Boyu Öğrenme ve Duyarlı Sevgi & 0.298 & $\mathbf{0 . 0 0 1}^{* *}$ \\
\hline r: Spearman Korelasyon Katsayısı & $* * p<0.01$ &
\end{tabular}

Otantik Liderlik Ölçeği ve Yaşam Boyu Öğrenme Eğilimleri Ölçeği toplam puanları arasında \%25,7 (r:0,257; p=0,001; $<<0.01$ ), Otantik Liderlik Ölçeği ve Duyarlı Sevgi Ölçeği toplam puanları arasında \%28,3 (r:0,283; $\mathrm{p}=0,001 ; \mathrm{p}<0.01)$ ile Yaşam Boyu Öğrenme Eğilimleri ve Duyarlı Sevgi Ölçeği toplam puanları arasında \%29,8 düzeyinde $(r: 0,298 ; p=0,001 ; p<0.01)$ pozitif yönlü istatistiksel olarak anlamlı ilişkiler saptanmıştır (Tablo 5).

\section{Otantik Liderlik Toplam Puanı Üzerine Risk Faktörleri Etkilerinin Lineer Regresyon Analizi Sonuçları}

Risk faktörleri olarak belirlenen; Yaşam Boyu Öğrenme Eğilimleri Ölçeği "Motivasyon", "Sebat", "Öğrenmeyi düzenlemede yoksunluk" ile "Merak yoksunluğu" puanları, duyarlı sevgi puanı ve cinsiyetin Otantik Liderlik Ölçeği toplam puanı üzerine etkilerini göstermek için lineer regresyon analizi uygulanmış, risk faktörlerinin Otantik Liderlik Ölçeği toplam puanı düzeyi üzerine etki derecelerini gösteren model özeti Tablo 6'da sunulmuştur.

Tablo 6: Risk faktörlerinin Otantik Liderlik Ölçeği toplam puanı üzerine etkileri

\begin{tabular}{|c|c|c|c|c|}
\hline & \multicolumn{2}{|c|}{$\begin{array}{l}\text { Standardize Edilmiş } \\
\text { Katsayllar }\end{array}$} & \multicolumn{2}{|c|}{$\begin{array}{l}95.0 \% \\
\text { B için Güven Aralıkları }\end{array}$} \\
\hline & $\mathbf{B}$ & $p$ & Alt Sinır & Üst Sınır \\
\hline \multicolumn{5}{|l|}{ Tüm olgularda } \\
\hline Motivasyon & 0.26 & $0.001 * *$ & 0.20 & 0.76 \\
\hline Sebat & -0.06 & 0.408 & -0.34 & 0.14 \\
\hline Öğrenmeyi düzenlemede yoksunluk & 0.21 & $0.013 *$ & 0.06 & 0.49 \\
\hline Merak yoksunluğu & -0.08 & 0.350 & -0.22 & 0.08 \\
\hline Duyarlı Sevgi & 0.12 & $0.030 *$ & 0.01 & 0.10 \\
\hline \multicolumn{5}{|l|}{ Erkek olgularda } \\
\hline Motivasyon & 0.34 & $0.001 * *$ & 0.28 & 0.93 \\
\hline Sebat & -0.05 & 0.588 & -0.35 & 0.20 \\
\hline Öğrenmeyi düzenlemede yoksunluk & 0.21 & $0.030^{*}$ & 0.03 & 0.50 \\
\hline Merak yoksunluğu & -0.11 & 0.271 & -0.26 & 0.07 \\
\hline Duyarl1 Sevgi & 0.10 & 0.122 & -0.01 & 0.10 \\
\hline \multicolumn{5}{|l|}{ Kadin olgularda } \\
\hline Motivasyon & 0.11 & 0.392 & -0.31 & 0.79 \\
\hline Sebat & -0.16 & 0.264 & -0.83 & 0.23 \\
\hline Öğrenmeyi düzenlemede yoksunluk & 0.12 & 0.477 & -0.33 & 0.69 \\
\hline Merak yoksunluğu & 0.08 & 0.655 & -0.27 & 0.42 \\
\hline Duyarlı Sevgi & 0.18 & 0.072 & -0.01 & 0.21 \\
\hline
\end{tabular}

Tüm olgular için model, anlamlı olup $(\mathrm{p}=0,001 ; \mathrm{p}<0.01)$, risk faktörleri otantik liderlik toplam puanı düzeyini $\% 12,1$ oranında $\left(\mathrm{R}^{2}=0,121\right)$ etkilemektedir. 
Yapılan regresyon analizi sonucunda otantik liderlik üzerine motivasyon, öğrenmeyi düzenlemede yoksunluk ve duyarlı sevgi puanının modelde anlamlı etkileri olduğu görülmektedir.

Cinsiyetler bazında incelendiğinde model, erkek olgular için anlamlı olup ( $p=0,001 ; p<0.01)$, risk faktörleri otantik liderlik toplam puanı düzeyini $\% 15,8$ oranında $\left(\mathrm{R}^{2}=0,158\right)$ etkilemektedir.

Yapılan regresyon analizi sonucunda otantik liderlik üzerine motivasyon ve öğrenmeyi düzenlemede yoksunluk puanlarının modelde anlamlı etkileri olduğu görülmektedir. Kadın olgular için model anlamlı bulunmamıştır ( $p=0,125 ; \mathrm{p}>0.05)$.

Cinsiyetlere göre Otantik Liderlik Ölçeği toplam ve alt boyut puanları arasında istatistiksel olarak anlamlılık saptandığından regresyon modellerinin cinsiyetlerde ayrı ayrı değerlendirilmesinin yararlı olacağı düşünülmüştür.

\section{Otantik Liderlik Alt Boyut Puanları Üzerine Risk Faktörleri Etkilerinin Lineer Regresyon Analizi Sonuçları}

Risk faktörleri olarak belirlenen Yaşam Boyu Öğrenme Eğilimleri Ölçeği "Motivasyon", "Sebat", "Öğrenmeyi düzenlemede yoksunluk", "Merak yoksunluğu” puanları ve duyarlı sevgi puanı ile cinsiyetin Otantik Liderlik Ölçeği alt boyut puanları üzerine etkilerini göstermek için lineer regresyon analizi uygulanmış, risk faktörlerinin otantik liderlik boyut puanlarına etki derecelerini gösteren model özeti Tablo 7'de sunulmuştur.

Erkek olgular için risk faktörlerinin Otantik Liderlik Ölçeği "İlişkilerde şeffaflık" puanı üzerine etkilerinin incelendiği regresyon modeli anlamlı olup $(\mathrm{p}=0,001 ; \mathrm{p}<0.01)$, risk faktörlerinin otantik liderlik toplam puanını \%11,9 oranında $\left(\mathrm{R}^{2}=0,119\right)$ etkilediği görülmektedir.

Yapılan regresyon analizi sonucunda, ilişkilerde şeffaflık üzerine motivasyon ve öğrenmeyi düzenlemede yoksunluk puanının modelde anlamlı etkileri olduğu izlenmektedir. Kadın olgular için modelimiz anlamlı bulunmamıştır $(\mathrm{p}=0,075 ; \mathrm{p}>0.05)$.

Erkek olgular için risk faktörlerinin Otantik Liderlik Ölçeği “İçselleştirilmiş ahlak anlayışı” puanı üzerine etkilerinin incelendiği regresyon modeli anlamlı bulunmuş $(p=0,001 ; p<0.01)$, risk faktörlerinin otantik liderlik toplam puanı düzeyini $\% 12,5$ oranında $\left(\mathrm{R}^{2}=0,125\right)$ etkilediği görülmüştür. Yapılan regresyon analizi sonucuna göre, içselleştirilmiş ahlak anlayışı üzerine motivasyon, öğrenmeyi düzenlemede yoksunluk ve merak yoksunluğu puanının modelde anlamlı etkileri bulunmaktadır. Kadın olgular için de model anlamlı olup $(\mathrm{p}=0,048 ; \mathrm{p}<0.05)$, risk faktörleri içselleştirilmiş ahlak anlayışı düzeyini $\% 9.2$ oranında $\left(\mathrm{R}^{2}=\right.$ 0,092) etkilemektedir. Yapılan regresyon analizi sonucunda içselleştirilmiş ahlak anlayışı üzerine duyarlı sevgi puanının modelde anlamlı etkileri olduğu görülmektedir. 
Tablo 7: Risk faktörlerinin Otantik Liderlik Ölçeği alt boyut puanları üzerine etkileri

\begin{tabular}{|c|c|c|c|c|c|}
\hline \multirow{2}{*}{$\begin{array}{l}\text { Otantik } \\
\text { Liderlik } \\
\text { Ölçeği }\end{array}$} & & \multicolumn{2}{|l|}{$\begin{array}{l}\text { Standardize } \\
\text { Edilmiş } \\
\text { Katsayılar } \\
\end{array}$} & \multicolumn{2}{|c|}{$\begin{array}{l}95,0 \% \\
\text { B için Güven Aralıkları }\end{array}$} \\
\hline & & B & $p$ & Alt Sinır & Üst Sınır \\
\hline \multirow{12}{*}{ 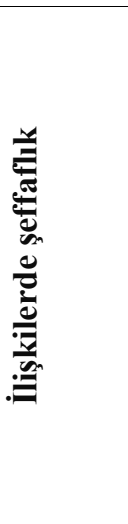 } & Erkek olgularda & & & & \\
\hline & Motivasyon & 0.23 & $0.012 *$ & 0.03 & 0.26 \\
\hline & Sebat & -0.05 & 0.619 & -0.12 & 0.07 \\
\hline & Öğrenmeyi düzenlemede yoksunluk & 0.22 & $0.029 *$ & 0.01 & 0.28 \\
\hline & Merak yoksunluğu & -0.05 & 0.655 & -0.07 & 0.05 \\
\hline & Duyarlı sevgi & 0.09 & 0.186 & -0.01 & 0.03 \\
\hline & Kadın olgularda & & & & \\
\hline & Motivasyon & 0.15 & 0.265 & -0.08 & 0.28 \\
\hline & Sebat & -0.15 & 0.292 & -0.26 & 0.08 \\
\hline & Öğrenmeyi düzenlemede yoksunluk & 0.30 & 0.075 & -0.02 & 0.32 \\
\hline & Merak yoksunluğu & -0.11 & 0.546 & -0.16 & 0.08 \\
\hline & Duyarlı sevgi & 0.15 & 0.127 & -0.01 & 0.06 \\
\hline \multirow{12}{*}{ 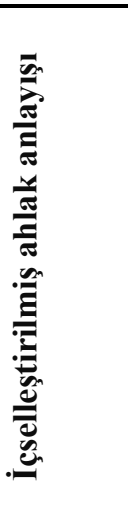 } & Erkek olgularda & & & & \\
\hline & Motivasyon & 0.32 & $0.001 * *$ & 0.07 & 0.24 \\
\hline & Sebat & -0.04 & 0.634 & -0.09 & 0.06 \\
\hline & Öğrenmeyi düzenlemede yoksunluk & 0.21 & $0.034 *$ & 0.01 & 0.13 \\
\hline & Merak yoksunluğu & -0.21 & $0.045^{*}$ & -0.09 & -0.00 \\
\hline & Duyarlı sevgi & 0.10 & 0.117 & -0.00 & 0.03 \\
\hline & Kadın olgularda & & & & \\
\hline & Motivasyon & 0.00 & 0.997 & -0.16 & 0.16 \\
\hline & Sebat & -0.09 & 0.508 & -0.20 & 0.10 \\
\hline & Öğrenmeyi düzenlemede yoksunluk & 0.11 & 0.523 & -0.10 & 0.19 \\
\hline & Merak yoksunluğu & 0.09 & 0.624 & -0.07 & 0.12 \\
\hline & Duyarlı sevgi & 0.26 & $0.008 * *$ & 0.01 & 0.07 \\
\hline \multirow{12}{*}{  } & Erkek olgularda & & & & \\
\hline & Motivasyon & 0.39 & $0.001 * *$ & 0.09 & 0.25 \\
\hline & Sebat & -0.05 & 0.535 & -0.09 & 0.05 \\
\hline & Öğrenmeyi düzenlemede yoksunluk & 0.12 & 0.222 & -0.02 & 0.09 \\
\hline & Merak yoksunluğu & -0.06 & 0.563 & -0.05 & 0.03 \\
\hline & Duyarlı Sevgi & 0.07 & 0.275 & -0.01 & 0.02 \\
\hline & Kadın olgularda & & & & \\
\hline & Motivasyon & 0.13 & 0.322 & -0.07 & 0.20 \\
\hline & Sebat & -0.21 & 0.138 & -0.23 & 0.03 \\
\hline & Öğrenmeyi düzenlemede yoksunluk & 0.04 & 0.812 & -0.11 & 0.14 \\
\hline & Merak yoksunluğu & 0.18 & 0.326 & -0.04 & 0.13 \\
\hline & Duyarlı sevgi & 0.16 & 0.116 & -0.01 & 0.05 \\
\hline \multirow{12}{*}{ Oَ } & Erkek olgularda & & & & \\
\hline & Motivasyon & 0.24 & $0.012 *$ & 0.03 & 0.24 \\
\hline & Sebat & -0.02 & 0.798 & -010 & 0.08 \\
\hline & Öğrenmeyi düzenlemede yoksunluk & 0.16 & 0.107 & -0.01 & 0.14 \\
\hline & Merak yoksunluğu & -0.08 & 0.423 & -0.07 & 0.03 \\
\hline & Duyarlı sevgi & 0.08 & 0.235 & -0.01 & 0.03 \\
\hline & Kadın olgularda & & & & \\
\hline & Motivasyon & 0.11 & 0.404 & -0.10 & 0.23 \\
\hline & Sebat & -0.11 & 0.454 & -0.22 & 0.10 \\
\hline & Öğrenmeyi düzenlemede yoksunluk & -0.06 & 0.715 & -0.18 & 0.12 \\
\hline & Merak yoksunluğu & 0.16 & 0.379 & -0.06 & 0.15 \\
\hline & Duyarlı sevgi & 0.06 & 0.587 & -0.02 & 0.04 \\
\hline
\end{tabular}


Erkek olgular için risk faktörlerinin Otantik Liderlik Ölçeği "Bilgiyi dengeli değerlendirme" puanı üzerine etkilerinin incelendiği regresyon modeli anlamlı olup $(\mathrm{p}=0,001 ; \mathrm{p}<0.01)$, risk faktörlerinin otantik liderlik toplam puanı düzeyini $\% 16,1$ oranında $\left(\mathrm{R}^{2}=0,161\right)$ etkilediği izlenmektedir. Yapılan regresyon analizi sonucunda, bilgiyi dengeli değerlendirme üzerine motivasyon puanının modelde anlamlı etkileri olduğu görülmektedir. Kadın olgular için model anlamlı bulunmamıştır ( $p=0,118 ; p>0.05)$.

Erkek olgular için risk faktörlerinin Otantik Liderlik Ölçeği “Öz farkındalık” puanı üzerine etkilerinin incelendiği regresyon modeli anlamlı olup ( $\mathrm{p}=0,001 ; \mathrm{p}<0.01)$, risk faktörlerinin öz farkındalık puanı düzeyini $\% 9,0$ oranında $\left(\mathrm{R}^{2}=0,090\right)$ etkilediği belirlemiştir. Yapılan regresyon analizi sonucunda öz farkındalık üzerine motivasyon puanının modelde anlamlı etkileri olduğu görülmektedir. Kadın olgular için modelimiz anlamlı bulunmamıştır ( $p=0,745$; $\mathrm{p}>0.05)$.

\section{TARTIŞMA ve SONUÇ}

$\mathrm{Bu}$ çalışmada, spor bilimleri alanında yapılan liderlik çalışmalarına yeni bir bakış kazandırmada katkı yaratacağı düşünülen otantik liderlik konusunu Spor Bilimleri Fakülteleri Antrenörlük Bölümleri Lisans öğrencileri ölçeğinde incelemek, bu bağlamda otantik liderliğin alt bileşenleri olan ilişkilerde şeffaflık, içselleştirilmiş ahlak anlayışı, bilginin dengeli ve tarafsız değerlendirilmesi ve öz farkındalık ile duyarlı sevgi becerilerinin yanı sıra motivasyon, sebat, öğrenmeyi düzenlemede yoksunluk ve merak yoksunluğu alt boyutlarını içeren yaşam boyu öğrenme eğilimleri arasındaki ilişkileri belirlemek amaçlanmıştır.

Katılımcıların otantik liderlik düzeyleri ile yaşam boyu öğrenme eğilimleri arasındaki korelasyon incelendiğinde yaşam boyu öğrenme ile otantik liderlik arasında istatistiksel olarak anlamlı bir ilişki saptanmıştır (r:0,257; $\mathrm{p}=0,001 ; \mathrm{p}<0.01)$. Yaşam boyu öğrenme düzeyi arttıkça otantik liderlik özellikleri göstermede bir artış olduğu, farklı bir ifade ile yaşam boyu öğrenme eğilimlerinin otantik liderliği pozitif yönde etkilediği söylenebilir. Bu bulgudan hareketle, yaşam boyu öğrenme eğiliminin temel göstergeleri olarak değerlendirilen; yüksek motivasyon, yaşam boyu öğrenmeye duyulan ilgi ve istek, yaşam boyu öğrenme etkinliklerine katılım, kendi öğrenme sorumluluğunu almak, alınan sorumluluk paralelinde zaman ve olanakları düzenleme, bireysel gelişim odağını yaşam boyu öğrenme faaliyetleri ile sürdürme irade ve özyeterliliğine ilişkin yetilerin bireylerde otantik liderlik özelliğinin ortaya çıkmasını teşvik edici rol üstlendiği anlaşılmaktadır.

Otantik liderlik düzeyi ile duyarlı sevgi arasındaki korelasyon incelendiğinde, katılımcıların duyarlı sevgileri ile otantik liderlikleri arasında istatistiksel olarak anlamlı bir ilişki saptandığı görülmektedir ( $r: 0,283 ; p=0,001 ; p<0.01)$. Buna göre, duyarlı sevgi düzeyi arttıkça otantik liderlik özelliklerini sergilemede bir artış olduğu, bir diğer ifadeyle duyarlı sevgi becerilerinin otantik liderliği olumlu yönde etkilediği söylenebilir. Bu olumlu etkiden yola çıkarak, başkalarına karşı sevecenlik ve pozitif ilgiyi temsil eden duyarlı sevginin yansımaları olan tüm insanlığa dönük ilgi ve duyarlılık, insanı önemseme, destekleme, yardım etme ve anlama üzerine yoğunlaşan duygu, düşünce ve davranışların artış kaydetmesinin otantik liderliğe 
özgü ilişkilerde şeffaflık, içselleştirilmiş ahlak anlayışı, bilgiyi dengeli değerlendirme ve öz farkındalık becerilerinde de artış yaratacağı öngörülebilir.

Katılımcıların yaşam boyu öğrenme eğilimleri ile duyarlı sevgi düzeyleri arasında da istatistiksel olarak anlamlı bir ilişki bulunmuştur ( $r: 0,298 ; p=0,001 ; p<0.01)$. Bu ilişkiye dayanarak, denilebilir ki, yaşam boyu öğrenme eğilimleri arttıkça antrenörlük lisans öğrencilerinin duyarlı sevgileri de artmakta, yaşam boyu öğrenme eğilimleri duyarlı sevgiyi pozitif yönde etkilemektedir.

Yapılan regresyon analizlerinde, otantik liderlik düzeyi toplam puanı üzerine Yaşam Boyu Öğrenme Eğilimleri Ölçeğinin "Motivasyon” ile “Öğrenmeyi düzenlemede yoksunluk" puanları ve duyarlı sevgi ölçek puanının etkileri anlamlı bulunmuştur (Tablo 6). Cinsiyetlere göre ayrı ayrı incelenen modellerde kadın antrenörlerde, sadece otantik liderlik düzeylerinden içselleştirilmiş ahlak anlayışı puanı üzerine duyarlı sevgi toplam puanının etkisi anlamlı olarak saptanırken; otantik liderlik toplam puanı ve diğer alt boyut puanlarına ilişkin regresyon modelleri anlamlı bulunmamıştır (Tablo 6, Tablo 7). Ancak erkek antrenörlerde, Yaşam Boyu Öğrenme Eğilimleri Ölçeğinin toplam puanında ve tüm alt boyutlarda modeller anlamlı bulunmuş olup özellikle motivasyonun etkisi tüm modellerde kendini göstermiştir. Erkek antrenörlerde otantik liderlik toplam puanı ve ilişkilerde şeffaflık puanı üzerine motivasyon ve öğrenmeyi düzenlemede yoksunluk puanlarının etkisi anlamı bulunmuştur (Tablo 6). İçselleştirilmiş ahlak anlayışı puanı üzerine motivasyon, öğrenmeyi düzenlemede yoksunluk ve merak yoksunluğu puanının etkileri anlamlı bulunmuştur. Bilgiyi dengeli değerlendirme ve öz farkındalık alt boyut puanları üzerine yine motivasyon puanının anlamlı etkisi olduğu görülmektedir.

Toor ve Ofari (2009:310), araştırmalarında otantik özelliklerin, psikolojik esenlikle güçlü ve anlamlı ilişkisi olduğunu, otantik liderlik özelliklerinin, sağlıklı psikolojik işlevlerin ve işle ilgili pozitif sonuçların ortaya çıkmasında etkili olduğunu ortaya koymuştur. Gündoğdu ve İslamoğlu'nun (2012) otantik liderlik davranışlarının, bireylerin işlerine dair duygusal iyilik algılarına katkısı ve yöneticilerine karşı hissettikleri güvenin, bu ilişkideki şartlı rolünü anlamaya yönelik çalışmalarında otantik liderlik davranışı ile işe ilişkin duygusal iyilik algısı arasında anlamlı derecede ve pozitif bir ilişki olduğu bulunmuştur. Gül ve Alacalar (2015), otantik liderlik bileşenleri olan öz farkındalık, bilginin dengeli değerlendirilmesi, ilişkilerde şeffaflık ve içselleştirilmiş ahlak anlayışının tümü ile izleyicilerin duygusal bağlılıkları ve performansları arasında olumlu ilişki tespit etmişlerdir.

$\mathrm{Bu}$ araştırmanın bulguları, Spor Bilimleri Fakülteleri Antrenörlük öğrencilerinin otantik liderlik özelliklerinin yüksek düzeyde olduğunu göstermektedir. Elde edilen sonuç ile yukarıda verilen araştırma sonuçları arasında paralellik kurarak; otantik liderlik düzeyi yüksek antrenörlerin sporcularda sağlıklı psikolojik işlevler ile artan duygusal iyilik algısının ortaya çıkmasında olduğu gibi sportif yaşamın gereği olan iş başarımı ile ilgili olumlu sonuçlara erişilmesinde üst düzey etki yaratabilecekleri öngörülebilir. 
Öte yandan, yine bulgulardan hareketle; Kerfoot (2006:116-117) ile Hassan ve Ahmed'in (2011:1036-1038) örgüt ortamı, otantik liderler ve çalışanlar arasındaki etkileşim hakkındaki görüşlerinden de yola çıkarak denilebilir ki, sporcular başarıyı hedefleyen kariyer yollarında kendileri ile yürekten iletişim kuran ve kendilerine ilham veren liderlik becerileri yüksek antrenörler isterler. Tam da bu noktada, otantik liderlik vasıflarını taşıyan antrenörlerin devreye girmesi; bir yandan içlerindeki tutkunun sağladığı enerjiden güç alarak doğru olanı oyuncu/sporculara gösterirken, diğer yandan sportif ortamda geliştirdikleri ve sürdürdükleri güven ve şeffaflık özellikleriyle ortama aktardıkları takıma bağlılık, iş doyumu, sorumluluk üstlenme isteklilikleri gibi değerler, bütünün olumlu sonuçlara ulaşmasında önemli işlevlerin yerine getirilmesini sağlar.

Araştırmada elde edilen bulgu ve sonuçlar doğrultusunda; antrenörler için yaşam boyu öğrenme etkinliklerinin planlanması, bu planlamada grubun ilgi ve gereksinimlerinin öncelikle dikkate alınması, bu yolla yaşam boyu öğrenme faaliyetlerine aktif katılım gösteren bireyler olmalarının özendirilmesi önerilmektedir. Bu yolla, antrenörlerin; sahada ve saha dışında sportif yaşam kalitesinin temsilcileri olarak duyarlılıklarının geliştirilerek yönlendirilebileceği, yetkinliklerinin artırılacağı, spora özgü etik duruşu koruyan, öz farkındalığı gelişmiş, kişiler arası ilişkilerde şeffaflı̆̆ 1 gözeten, bilgiyi sadece dengeli değil aynı zamanda yenilikçi, ilerletici ve yaratıcı biçimde kuşaklar arası boyuta taşıyan önderler olmalarının özendirileceği düşünülmektedir. Dolayısıyla, spora özgü değişim, dönüşüm ve ilerleme olgularının teslim edildiği böylesi liderlerin salt sportif gelişimi değil sosyal yaşamda yüceltilen rol modeller olmaları sebebiyle ayrıca toplumun sosyo-kültürel esenlik yaşantılarını da yükseltici etki yaratmaları beklenmektedir.

\section{KAYNAKLAR}

Akdeniz, S., ve Deniz, M. E. (2016). Merhamet Ölçeği'nin Türkçeye uyarlanması: Geçerlik ve güvenirlik çalışması. The Journal of Happiness \& Well-Being, 4(1), 50-61.

Akın, A., ve Eker, H. (2012). Duyarlı Sevgi Ölçeği: Geçerlik ve Güvenirlik Çalışması. Uludă̆ Üniversitesi Eğitim Fakültesi Dergisi, 25(1), 75-85.

Akkuş, N. (2008). Yaşam boyu öğrenme becerilerinin göstergesi olarak 2006 PISA sonuçlarının Türkiye açısından değerlendirilmesi. Yayımlanmamış Yüksek Lisans Tezi, Hacettepe Üniversitesi, Sosyal Bilimler Enstitüsü, Ankara.

Antikainen, A. (2001). Is life learning becoming a reality? The case of Finland from a comparative perspective. European Journal of Education, 36(3), 379-394.

Avolio, B. J., \& Gardner, W. L. (2005). Authentic leadership development: Getting to the root of positive forms of leadership. The leadership quarterly, 16(3), 315-338.

Avolio, B. J., Walumbwa, F. O., \& Weber, T. J. (2009). Leadership: Current theories, research, and future directions. Annual review of psychology, 60, 421-449.

Batson, C.D., \& Oleson K. C. (1991). Current Status of the Empathy-Altruism Hypothesis. In M. S. Clark (Ed.) Rewiew of Personality and Social Psychology (pp. 62-85). Newbury Park, CA: Sage.

Büyüköztürk, Ş., Kılıç Çakmak, E., Akgün E., Karadeniz, Ş., ve Demirel F. (2015). Bilimsel Araştırma Yöntemleri. 19. Basım. Ankara: Pegem Akademi, s. 23, 195. 
Clapp-Smith, R., Vogelgesang, G. R., \& Avey, J. B. (2009). Authentic leadership and positive psychological capital: The mediating role of trust at the group level of analysis. Journal of Leadership \& Organizational Studies, 15(3), 227-240.

Cropley, A.J., \& Dave, R.H. (1978). Lifelong education and the training of teachers. Oxford: Pergamon Press.

Diker Coşkun, Y., (2009). Üniversite öğrencilerinin yaşam boyu öğrenme ĕgilimlerinin bazı değişkenler açısından incelenmesi. Yayımlanmamış Doktora Tezi, Hacettepe Üniversitesi, Sosyal Bilimler Enstitüsü, Ankara.

Doğan, O. (2015). Spor psikolojisi. 3. Basım. Ankara: Detay Yayıncılık, s. 173, 176-177.

Donuk, B. (2007). Liderlik ve spor. İstanbul: Ötüken Neşriyat, s. 145.

Eker, H. (2011). Üniversite öğrencilerinin öz-duyarlık ve duyarlı sevgi düzeylerinin ebeveyn tutumları açısından incelenmesi. Yayımlanmamış Yüksek Lisans Tezi, Sakarya Üniversitesi, Eğitim Bilimleri Enstitüsü, Sakarya.

Erçil, Y. (2012). Yeni dünya ve liderlik paradigması. içinde A. Tabak, H. Şeşen, T. Türköz (Eds). Liderlikte Güncel Yaklaşımlar ve Uygulamada Kullanılabilecek Ölçekler (ss. 75-91.) Ankara: Detay Yayıncılık.

Fehr, B., Sprecher S., \& Underwood L. G. (2009). The Science of Compassionate Love. Theory, Research and Applications. UK: Blackwell Publishing. p. 4.

Gardner, W. L., Avolio, B. J., Luthans, F., May, D. R., \& Walumbwa, F. (2005). Can you see the real me? a self-based model of authentic leader and follower development. The Leadership Quarterly, 16(3):343372.

George, B. (2003). Authentic leadership: Rediscovering the secrets to creating lasting value. San Fransisko, CA: Jossay-Bass A Wiley Imprint, John Wiley \& Sons, Inc.. pp. 11-12.

Gül, H., ve Alacalar A. (2014). Yaşam Boyu Öğrenme Nedir? Kavram ve Kapsamı Üzerine Bir Değerlendirme. Akademik Sosyal Araştırmalar Dergisi, 2(5), 540-550.

Güleç, İ., Çelik, S., ve Demirhan, B. (2012). Yaşam Boyu Öğrenme Nedir? Kavram ve Kapsamı Üzerine Bir Değerlendirme. Sakarya Üniversitesi Eğitim Fakültesi Dergisi, 2(3), 34-48.

Gündoğdu, Z., ve İslamoğlu, G. (2012). Otantik Liderlik Davranışının Çalışanların İşe İlişkin Duygusal İyilik Algıları Üzerindeki Katkısı ve Yöneticiye Güvenin Bu İlişki Üzerindeki Şartlı Rolü, 20. Ulusal Yönetim ve Organizasyon Kongresi. İzmir, Türkiye.

Günüç, S., Odabaşı, H. F., ve Kuzu, A. (2012). Yaşam boyu öğrenmeyi etkileyen faktörler. Gaziantep Üniversitesi Sosyal Bilimler Dergisi, 11(2), 309-325.

Harter, S. (2002). Authenticity. In C. R. Snyder \& S. J. Lopez (Eds.), Handbook of Positive Psychology (pp. 382-394). New York, NY, US: Oxford University Press.

Hassan, A., \& Ahmed, F. (2011). Authentic leadership, trust and work engagement. International Journal of Social, Behavioral, Educational, Economic, Business and Industrial Engineering, 5(8), 1036-1042.

Ilıman, A. Y., (2017). Klasik ve entegre eğitim modeli ile öğrenim gören hemşirelik ögrencilerinde problem çözme becerisi ve yaşam boyu ögrenme eğilimi. Yayımlanmamış Yüksek Lisans Tezi, Marmara Üniversitesi, Sağlık Bilimleri Enstitüsü, İstanbul.

Ilies, R., Morgeson, F. P., \& Nahrgang, J. D. (2005). Authentic leadership and eudaemonic well-being: Understanding leader-follower outcomes. The Leadership Quarterly, 16(3), 373-394.

Kaçmazoğlu, H. B. (Ocak 2002). Doğu-Batı Çatışması Açısından Globalleşme. Eğitim Araştırmaları 6: 44-55. 
Kerfoot, K. (2006). Authentic leadership. Nursing economics, 24(2), 116-117.

Kernis, M. H. (2003). Toward A Conceptualization of Optimal Self-Esteem. Psychological Inquiry, 14(1), 1-26.

K1lıç, H., (2015). Illkögrretim branş ögretmenlerinin bireysel yenilikçilik düzeyleri ve yaşam boyu ögrenme eğilimleri (Denizli ili örneği). Yayımlanmamış Yüksek Lisans Tezi, Pamukkale Üniversitesi, Eğitim Bilimleri Enstitüsü, Denizli.

Knapper, C., \& Cropley, A. (2000). Lifelong Learning in Higher Education. London: Kogan Page.

Konter, E. (1996). Bir Lider Olarak Antrenör. İstanbul: Alfa Basım Yayım Dağıtım, s. 9.

Konter, E. (2004). Antrenörlük ve Takım Psikolojisi. Ankara: Palme Yayınc1lık, s. 16.

Korkut, E., ve Akkoyunlu, B., (2008). Yabancı Dil Öğretmen Adaylarının Bilgi ve Bilgisayar Okuryazarlık Özyeterlikleri. Hacettepe Üniversitesi Eğitim Fakültesi Dergisi, 34, 178-188.

Lazarus, R. S. (1991). Emotion and Adaptation. New York: Oxford University Press. p. 289.

Martens, R. (1998). Başarılı Antrenörlük. İstanbul: Beyaz Yayınları, s. 11.

Peck, M. S. (2009). Az seçilen yol: Sevginin, geleneksel değerlerin ve ruhsal tekâmülün psikolojisine yeni bir bakış (Çev. R. Özer). İstanbul: Akaşa Yayınları., s. 81.

Preece, J. (2006). Beyond the learning society: the learning world? International Journal of Lifelong Education, 25(3), 307-320.

Saroglou, V. (2015). Din, maneviyat ve diğerkâmlık. (Çev. M. Şahin). Çanakkale Onsekiz Mart Üniversitesi Ilahiyat Fakültesi Dergisi, 7, 113-145.

Saylı, H., ve Baytok, A. (2014). Örgütlerde Liderlik Teori-Uygulama ve Yeni Perspektifler. Ankara: Nobel Yayıncılık., s. 12.

Serin, K., (2016). Boks Antrenörlerinin Liderlik Tarzlarının Belirlenmesi. Yayımlanmamış Yüksek Lisans Tezi, Selçuk Üniversitesi, Sağlık Bilimleri Bilimleri Enstitüsü, Konya.

Shamir, B., \& Eilam, G. (2005). "What's your story?" A life-stories approach to authentic leadership development. The leadership quarterly, 16(3), 395-417.

Sorokin, P. A. (2005). Özgeci Sevgi (Çev. M. Harmanc1). İçinde Kirch A. (Ed.) Aşkın Anatomisi (ss. 221-233). İstanbul: Say Yayınları.

Sönmez, V. (2014). Eğitim Felsefesi. 12. basım. Ankara: Anı Yayıncılık, s. 34-38.

Sparrowe, R. T. (2005). Authentic Leadership and the Narrative Self. The Leadership Quarterly, 16(3), 419439.

Sprecher, S., \& Fehr, B. (2005). Compassionate love for close others and humanity. Journal of Social and Personal Relationships, 22(5), 629-651.

Şenyuva, E. (2013). Hemşirelikte Yaşam Boyu Öğrenme: Algılar ve Gerçekler. İstanbul Üniversitesi Florence Nightingale Hemşirelik Dergisi, 21(1), 69-75.

Tabak, A., Sığrı, Ü., Arlı, Ö., ve Coşar, S. (2010). Otantik Liderlik Ölçeğinin Uyarlama Çalışması. 18. Yönetim ve Organizasyon Kongresi Kongre Bildiriler Kitab1, 699-706.

Toor, S. U. R., \& Ofori, G. (2008). Leadership for future construction industry: agenda for authentic leadership. International Journal of Project Management, 26(6), 620-630. 
Toor, S. U. R., \& Ofori, G. (2009). Authenticity and its influence on psychological well-being and contingent self-esteem of leaders in Singapore construction sector. Construction Management and Economics, 27(3), 299-313.

Topaloğlu, T., ve Süral Özer, P. (2014). Psikolojik Sermaye ile İş Performansı Arasındaki İlişkiye Otantik Liderliğin Düzenleyici Etkisi. Organizasyon ve Yönetim Bilimleri Dergisi, 6(1), 156-171.

Turan, S. (2005). Öğrenen toplumlara doğru Avrupa Birliği eğitim politikalarında yaşam boyu öğrenme. Ankara Avrupa Çalışmaları Dergisi, 5(1), 87-98.

Underwood, L. G. (2009). Compassionate Love: A Frame work for Research. In Fehr, B., Sprecher S., \& Underwood L. G.(Eds.) The Science of Compassionate Love. Theory, Research and Applications (pp. 325). West Sussex, UK: Blackwell Publishing.

Walumbwa, F. O., Avolio, B. J., Gardner, W. L., Wernsing, T. S., \& Peterson, S. J. (2008). Authentic leadership: Development and validation of a theory-based measure. Journal of management, 34(1), 89126.

Wong, C. A., \& Cummings, G. G.(2009). The Influence of Authentic Leadership Behaviors on Trust and Work outcomes of Health Care Staff. Journal of Leadership Studies, 3(2), 6-23. 